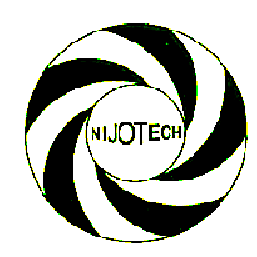

Nigerian Journal of Technology (NIJOTECH)

Vol. 33 No. 4, October 2014, pp. 559 - 565

Copyright(C) Faculty of Engineering,

University of Nigeria, Nsukka, ISSN: $1115-8443$

www.nijotech.com

http://dx.doi.org/10.4314/njt.v33i4.17

\title{
SURVEY OF OPERATORS KNOWLEDGE OF OPERATION AND MAINTENANCE OF FARM MACHINERY IN EBONYI STATE, NIGERIA
}

\author{
O. Oduma ${ }^{1}$, P. C Eze ${ }^{2, *}$ and M. E Igboke ${ }^{3}$ \\ 1DEPT OF AGRIC. AND BIORESOURCES ENGINEERING, MiCHAEL OKPARA UNIV. OF AGRICULTURE, UMUdiKE, NIGERIA. \\ 2Dept of AgriC. ANd BioResources EngineERING, ENUGu State Univ. of SCIENCE AND TECH., ENUGU, NiGERIA. \\ 3UNITED NATIONS INDUSTRIAL DEVELOPMENT ORGANIZATION (UNIDO), ABAKALIKI, EBONYI STATE, NIGERIA. \\ E-mail addresses:1 odumaoke@gmail.com.2ezepaul2@yahoo.com ${ }^{3}$ soloeze@yahoo.co.uk
}

\begin{abstract}
A survey was carried out to access the operators' knowledge of operation and maintenance of farm machinery for sustainable agricultural mechanisation in Ebonyi State, Nigeria. The questionnaires, oral interviews/interactions and field investigations were used to ascertain the operators' educational background, experience on machine operation and maintenance in the government and private agricultural organisation in the study area. The survey revealed that $44.6 \%$ of the operator had both primary education and trade test; $26.9 \%$ had primary education only. 19.3\% had trade test certificate only and 9.2\% had post-primary education and trade test certificate. All the respondents were licensed to operate machines. The mean age and year of experienced of the operators were 41.05 and 19.8 years respectively. The statutory result on the machines indicated that $64.9 \%$ of the available machines were functional, $21.9 \%$ were non-functional but serviceable while $14.5 \%$ were non-functional but unserviceable. 50.4 to $79.8 \%$ of the operators examined from both government and private agricultural organisations could competently handle preventive and corrective maintenances while 17 to $20 \%$ had little knowledge of maintenance and about 2 to $10 \%$ had no knowledge of maintenance. Result showed that the machine failures encountered during operations were as a result of poor management, inadequate maintenance practices, and lack of spare parts, obsoleteness, overloading, careless operations and poor storage of machine after use. Recommendations were therefore given to improve the operation and maintenance of machinery in the area.
\end{abstract}

Keywords: machinery operation, operator's knowledge, maintenance, farm mechanization, Ebonyi state.

\section{INTRODUCTION}

Farm machinery can be defined as a general term used to describe tractors, combines, implements, machines and other devices more sophisticated than hand tools which may be animal or mechanically powered at the farm level [1]. According to [2], they include ploughs, harrows, rotovators, ridgers, seeders/seed drills and planters, cultivators, harvesters; haying machines, processing machines such as silage cutter, feed grinders, cotton gins, threshers, trucks and tractors. As these machines are engaged in tasks or field operations, they are subjected to a very high force in order to perform the job/tasks. The vibrations of the various parts of the machines during operation lead to wear, tear and/or loosening of some parts that are in contact and are rubbing themselves and as such demand some human attention to extend the useful life of the machine. The production efficiency of farm machinery depends on the attention paid to its maintenance. It is the surest way to minimize production cost and reduce breakdown time [3]. The effectiveness of a machine working system depends not only on the innate properties built into it, in the designing and production stages but also on the quality of its operation, maintenance and repair [4]. Maintainability of any farm machinery/equipment is a parameter that minimises the down time of such machinery or equipment [5]. According to [6] it was stated that maintenance of equipment and machinery in any form is a nuisance demanding enormous resources of manpower and materials. They maintained that, it is absolutely essential if plant,

* Corresponding author, Tel: +234-803-264-2304 
machinery and equipment are to remain in good working conditions and ready for use when they are required. The decision is never whether maintenance should take place, but the form it should take to make it economically effective. Thus, maintenance nowadays, like any other economic activities is subjected to management policy, consideration and decision.

Different authors have different definitions for maintenance; [7] defines maintenance as concerned with day-to-day problems of keeping the physical plant in good operating condition according to standard set by management. [8] sees maintenance as any activity designed to keep equipment, or other assets in working condition. Also [9] defines maintenance as activities undertaken in order to keep or restore every facility to an acceptable standard and may be planned or unplanned. One thing common among all the definitions is that they all imply that maintenance in the broad sense can be taken as a combination of all technical and associated administrative actions intended to retain an item in or restore it to, a state in which it can perform its required function [6]. Every machine will require maintenance even if it is best designed; hence, the maintenance must be done at such a time when it may have least disruptions in its operation [10]. Machines may be thoroughly tested and inspected by the manufactures before selling it and by the purchaser before it is put to use. When it is used, it will be subjected to wear and tear as earlier stated, hence proper attention should be given to protect the machine and its components from undue wear and failure. To achieve this, machines have to be handled by trained operators who have adequate knowledge and skills in machine operation and maintenance, in order to minimize the frequency of its breakdown. Effective machinery maintenance involves proper equipment handling, cleaning and oil lubrications, bearing greasing, replacement of worn out parts with new ones and repairs [11]. Farm machineries such as tractors are very costly machines that worth millions of naira hence need to be operated by trained operators as tractor operation with different implements requires special knowledge, skill and training. Poor operational knowledge, skill and inadequate facilities to maintain farm machineries among other factors hinder agricultural mechanization in Nigeria. Ebonyi State is an agrarian area, hence, the name salt of the nation is traceable from her agricultural activities; one major reason for the low level of their output most times is low level of agricultural mechanization resulting from poor financial background of the farmers to procure farm machineries and poor maintenance practices. Agricultural mechanization according to [12] is the process of development and introduction of mechanized assistance of all forms and at any level of sophistication in agricultural production in order to reduce human drudgery, improve timeless and efficiency of various farm operations, bring more lands under cultivation, provide better rural living conditions and markedly advance the economic growth of the rural sectors. A sustainable agricultural mechanization among other things involves the application of Engineering principles and technology in selecting, testing, operating and maintenance of farm machineries in order to ensure maximum availability and reliability of those machineries.

The objectives of this research work are to investigate the status of the available machines and the extent of their operation for agricultural activities in Ebonyi State. Also to carry out a comprehensive survey of operators' knowledge of operation and maintenance of farm machinery and the possible causes of failures and maintenance practices applicable in the area with a view to recommend the ways that will enhance the farm machinery operation and maintenance for sustainable farm mechanization in Ebonyi State and other areas with similar cases.

\section{MATERIALS AND METHODS}

\subsection{Questionnaire Development and Administration}

The questionnaires were developed and distributed to mechanized agricultural organizations (government and private) in the study area to collect the necessary data during the planting season. The questionnaires consisted of three parts: Part 1; sought information on the personal data of the respondents, Part 2; was designed to provide information on the inventory and the status of the farm machinery available in the study area, while Part 3; sought information on the operators knowledge and skills of operation; facilities to maintain machines, causes of machine failures and maintenance practices applicable in the area. The study areas were zoned into five namely: A, B, C, D and E respectively for effective management. The questionnaires were administered to mechanized organizations such as Agricultural Department in the Local Government Secretariats, Ministry of Agriculture and Natural Resources, Ebonyi State Agricultural Development Program (EBADEP), Federal Ministry of 
Agriculture, Ebonyi State Chapter and mechanized private organizations/individuals.

The questionnaires were properly explained to the respondents who cannot read and write for them to understand the information while the researcher does the recording following their answers. Those that were able to read and write were allowed to have the copies of the questionnaires and were retrieved later after attending to the questions.

\subsection{Data Collection}

Data were collected from the information obtained from the structured questionnaires, oral interviews/interactions and field investigations. The data collected were properly studied and analyzed using descriptive statistical tables to reach at meaningful result, conclusion and recommendations.

\section{RESULTS AND DISCUSSION}

Table 1 revealed that operators within the age range of 30-39 years had the highest members with $56.3 \%$, followed by the operators with the range of $40-49$ years which made up $31.1 \%$ while $8.4 \%$ and $4.2 \%$ fall within the age range of 50-59 and 20-29 years respectively. The mean ages of the operators were 38.6, 42.3, 44.2 and 39.1 for local government, state government, federal government and private operators respectively. Their overall mean age was 41.05 years. The result obtained by [13] among Kwara state tractor operators with mean age of 41.51 years was closely related to the mean age of 41.05 years of sampled machinery operators studied.

Table 2 showed the educational status of the operators. $44.6 \%$ of the operators had both primary education and trade test. This is very close to half of the sampled operators. This was followed by $26.9 \%$ who had primary education only, $19.3 \%$ had trade test certificate only and the remaining $9.2 \%$ had post primary education with trade test certificate.

Table 3 revealed the working experiences of the operators. The result of this Table indicated that $24.4 \%$ of the operators had about $16-20$ years of experience. This was followed by $21.0 \%$ that had 21 25 years experience. About 19.3\% had 11-15 years experience; $14.3 \%$ had $6-10$ years experience; $12.6 \%$ had 26-30 years experience and $8.4 \%$ had 1-5 years of experience. The mean years of experience for the overall 119 sampled operators was found to be 19.8 years. The result revealed that for the 25 sampled local government operators, 32 state government 40 federal and 22 private operators, their mean years of experiences were found to be $19.3 ; 20.4 ; 24.7$ and 15.6 years respectively; implying that federal operators are most experienced, followed by state operators, the local government operators and the least were the private operators. From the result of the operators working experience, it can also be noticed that the operators experiences were reasonably high which may be attributed to early adoption of agricultural mechanization in the study area though with low advance rate which may be as a result of poor management policies or other factors.

Table 4 showed that all the sampled one hundred and nine (119) operators were licensed. This simply shows that possession of license may be the prerequisite for operators' employment in the area.

Table 5 presents the farm machinery inventory based on ownership in the study area. The result indicated that tractors and implements are mostly used in agricultural operations followed by shellers, mowers, threshers, trucks, sprayers and the least were the decorticators and cotton pickers. Groundnut, Bambara nut and cotton production are drastically low in the area and that may be why the adoption of decorticating and cotton picking machines were very low. The federal government owns the highest number of equipment followed by state government, local government and least was the private organization/individual.

Table 6 indicated the status of the available machinery in the study area. Result of this table showed that federal government shows most concern about maintenance of farm machinery having $30.4 \%, 4.9 \%$ and $3.6 \%$ of all the available farm machinery in terms of functional machines, non-functional serviceable and non-functional unserviceable machinery respectively. The least is the private organization/individuals with $3.8 \%, 3.1 \%$ and $2.8 \%$ for functional, non-functional serviceable and non-functional unserviceable machineries. The reason for low level of maintenance practices as noticed in the private sector may be as a result of financial constraints and/or poor management policies; despite that, the result of Table 6 generally revealed that there is drastic fall in the number of non-functional serviceable and nonfunctional unserviceable machineries in the study area, which imply that the extent of preventive and corrective maintenance as practiced in the area is somewhat commendable.

Table 7 presents the operators knowledge of machinery operation. Result from this table showed that 66.8 to $100 \%$ of the sampled operators were 
found competent in operating various machinery, $46.2 \%$ and $47.9 \%$ of the operators were detected to be capable to operate decorticators and cotton pickers. Reason may be due to inadequate decorating and cotton picking machines in the sampled organization studied resulting from the fact that the area does not produce such crops like groundnut, bambara nut and cotton in large quantities which will attract purchase of those machines.

Table 8 revealed that 50.4 to $79.8 \%$ of the operators in all the agricultural organisations surveyed can competently handle some of the preventive and corrective maintenances on the available farm machineries. About 17 to $20 \%$ have little knowledge about machine maintenance, while 2 to $10 \%$ have no knowledge of maintenance.

Finally, Table 9 reviewed the causes of failures of the various sampled farm machineries. Poor management policies accounted for $75.8 \%$ of the failures, lack of spare parts had $72.0 \%$, overloading $71.9 \%$ obsolete condition was $61.9 \%$, poor storage of equipment had $56 \%$ and poor maintenance had least of $31.6 \%$

In the light of foregoing, government (at local level, state or federal) and private agricultural organizations should provide adequate machinery especially those lacking ones to boost the production of such crops that are sparingly produced due to unavailability of such farm machines. This will enhance full mechanization of agricultural operations in Ebonyi State. In addition, workshops, seminars and course programmes on every machine operation and maintenance should be organized regularly to promote the operators knowledge and skills and generally sustain agricultural mechanization in the area.

Table 1: Age distribution of operators

\begin{tabular}{lcccccc}
\hline $\begin{array}{l}\text { Age } \\
\text { (yrs) }\end{array}$ & $\begin{array}{c}\text { Local } \\
\text { Govt. }\end{array}$ & $\begin{array}{c}\text { State } \\
\text { Govt. }\end{array}$ & $\begin{array}{c}\text { Federal } \\
\text { Govt. }\end{array}$ & $\begin{array}{c}\text { Private } \\
\text { Org/individuals }\end{array}$ & Total & Percentage of total (\%) \\
\hline $20-29$ & - & 4 & - & 1 & 5 & 4.2 \\
$30-39$ & 16 & 18 & 26 & 7 & 67 & 56.3 \\
$40-49$ & 5 & 8 & 11 & 13 & 37 & 31.1 \\
$50-59$ & 4 & 2 & 3 & 1 & 10 & 8.4 \\
$60-69$ and above & - & - & - & - & - & 100 \\
\hline Total & 25 & 32 & 40 & 22 & 119 & - \\
Mean (Years) & 38.6 & 42.3 & 44.2 & 39.1 & 41.05 & \\
\hline
\end{tabular}

Table 2: Educational background of the operators

\begin{tabular}{|c|c|c|c|c|c|c|}
\hline Qualification/certificate & $\begin{array}{l}\text { Local } \\
\text { Govt. }\end{array}$ & $\begin{array}{l}\text { State } \\
\text { Govt. }\end{array}$ & $\begin{array}{l}\text { Federal } \\
\text { Govt. }\end{array}$ & $\begin{array}{c}\text { Private } \\
\text { Org/Individuals }\end{array}$ & Total & $\begin{array}{c}\text { Percentage of total } \\
(\%)\end{array}$ \\
\hline Primary Education Cert. & 7 & 10 & 13 & 2 & 32 & 26.9 \\
\hline Trade Test Cert. Only. & 5 & 6 & 5 & 7 & 23 & 19.3 \\
\hline $\begin{array}{l}\text { Primary Education and Trade Test } \\
\text { Cert. }\end{array}$ & 10 & 14 & 19 & 10 & 53 & 44.6 \\
\hline $\begin{array}{l}\text { Post-Primary Education and Trade } \\
\text { Test }\end{array}$ & 3 & 2 & 3 & 3 & 11 & 9.2 \\
\hline Total & 25 & 32 & 40 & 22 & 119 & 100 \\
\hline
\end{tabular}

Table 3: Operators Working/Operation Experience

\begin{tabular}{lcccccc}
\hline Experience (yrs) & $\begin{array}{c}\text { Local } \\
\text { Govt. }\end{array}$ & $\begin{array}{c}\text { State } \\
\text { Govt. }\end{array}$ & $\begin{array}{c}\text { Federal } \\
\text { Govt. }\end{array}$ & $\begin{array}{c}\text { Private } \\
\text { Org/individuals }\end{array}$ & Total & Percentage of total (\%) \\
\hline $1-5$ & 2 & 3 & 4 & 1 & 10 & 8.4 \\
$6-10$ & 3 & 5 & 4 & 5 & 17 & 14.3 \\
$11-15$ & 4 & 6 & 7 & 6 & 23 & 19.3 \\
$16-20$ & 6 & 8 & 1 & 4 & 19 & 24.4 \\
$21-25$ & 3 & 5 & 9 & 4 & 25 & 21.4 \\
$26-30$ & 7 & 5 & 5 & 2 & 15 & 12.6 \\
31 and above & - & - & - & - & - & \\
\hline Total & 25 & 32 & 40 & 22 & 119 & \\
Mean & 19.3 & 20.4 & 23.7 & 15.6 & 19.8 & \\
\hline
\end{tabular}


Table 4: Acquisition of license

\begin{tabular}{lcccccc}
\hline $\begin{array}{l}\text { Licensed } \\
\text { Acquisition }\end{array}$ & $\begin{array}{l}\text { Local } \\
\text { Govt. }\end{array}$ & $\begin{array}{c}\text { State } \\
\text { Govt. }\end{array}$ & $\begin{array}{c}\text { Federal } \\
\text { Govt. }\end{array}$ & $\begin{array}{c}\text { Private } \\
\text { Org/individuals }\end{array}$ & Total & Percentage of total (\%) \\
\hline $\begin{array}{l}\text { Licensed } \\
\text { Operators }\end{array}$ & 25 & 32 & 40 & 22 & 119 & $100 \%$ \\
$\begin{array}{l}\text { Unlicensed } \\
\text { Operators }\end{array}$ & - & - & - & - & - & $0 \%$ \\
\hline
\end{tabular}

Table 5: Farm Machinery Inventory Based on Ownership

\begin{tabular}{llllll}
\hline & \multicolumn{5}{c}{ Ownership } \\
\cline { 2 - 6 } \multicolumn{1}{c}{ Machinery } & Local & State & Federal & $\begin{array}{c}\text { Private } \\
\text { Govg/Individuals }\end{array}$ & Total \\
& Govt. & Govt. & Govt. & 10 & 155 \\
\hline Tractors & 24 & 51 & 68 & 10 & 160 \\
Ploughs & 40 & 50 & 60 & 10 & 155 \\
Harrows & 33 & 50 & 62 & 10 & 106 \\
Cultivators & 18 & 35 & 44 & 10 & 122 \\
Ridgers & 28 & 40 & 50 & 7 & 92 \\
Planters & 20 & 33 & 32 & 5 & 88 \\
Seed dills & 15 & 25 & 40 & 8 & 142 \\
Shellers & 32 & 50 & 65 & 15 & 63 \\
Fertilizer Applicator & 6 & 17 & 37 & 3 & 106 \\
Mowers & 20 & 41 & 30 & 15 & 94 \\
Sprayers & 24 & 30 & 25 & 15 & 78 \\
Rice Combine Harvester & 20 & 30 & 26 & 2 & 101 \\
Threshers & 20 & 28 & 44 & 9 & 3 \\
Decorticators & - & 3 & - & - & 103 \\
Trucks & 14 & 27 & 33 & 29 & 3 \\
Cotton Picks & 3 & - & - & - & \\
\hline
\end{tabular}

Table 6: Status of the Available machinery

\begin{tabular}{|c|c|c|c|c|c|c|c|c|c|c|c|c|c|}
\hline \multirow[t]{2}{*}{ Machinery } & \multicolumn{4}{|c|}{ Functional } & \multicolumn{4}{|c|}{ Non-functional (Serviceable) } & \multicolumn{5}{|c|}{ Non-functional(unserviceable) } \\
\hline & $\begin{array}{l}\text { Local } \\
\text { Govt. }\end{array}$ & $\begin{array}{l}\text { State } \\
\text { Govt. }\end{array}$ & $\begin{array}{l}\text { Fed } \\
\text { Govt }\end{array}$ & $\begin{array}{l}\text { Private } \\
\text { org/ind }\end{array}$ & $\begin{array}{l}\text { local } \\
\text { govt. }\end{array}$ & $\begin{array}{l}\text { State } \\
\text { Govt }\end{array}$ & $\begin{array}{l}\text { Fed } \\
\text { Govt }\end{array}$ & $\begin{array}{l}\text { Private } \\
\text { org/ind }\end{array}$ & $\begin{array}{l}\text { Local } \\
\text { Govt. }\end{array}$ & $\begin{array}{l}\text { State } \\
\text { Govt }\end{array}$ & $\begin{array}{l}\text { Fed } \\
\text { Govt }\end{array}$ & $\begin{array}{l}\text { Private } \\
\text { org/ind }\end{array}$ & Total \\
\hline Tractors & 10 & 24 & 46 & 6 & 8 & 18 & 20 & 3 & 6 & 5 & 2 & 1 & 155 \\
\hline Ploughs & 26 & 28 & 40 & 8 & 9 & 15 & 10 & - & 5 & 7 & 10 & 2 & 160 \\
\hline Harrows & 15 & 25 & 45 & 5 & 12 & 10 & 11 & - & 6 & 15 & 4 & 5 & 155 \\
\hline Cultivators & 12 & 19 & 38 & 3 & 6 & 7 & 6 & 4 & - & 9 & - & 3 & 106 \\
\hline Ridgers & 17 & 24 & 46 & 7 & 4 & 11 & 2 & - & 7 & 5 & 2 & 3 & 122 \\
\hline Plants & 9 & 18 & 28 & 1 & 7 & 9 & - & 4 & 4 & 6 & 5 & - & 92 \\
\hline Seed drills & 7 & 15 & 37 & 5 & 5 & 6 & - & 2 & 4 & 4 & 3 & 1 & 88 \\
\hline Sheller & 20 & 30 & 46 & 2 & 6 & 12 & 9 & 9 & 6 & 8 & 10 & 4 & 142 \\
\hline $\begin{array}{l}\text { Fertilizer } \\
\text { Applicator }\end{array}$ & 5 & 10 & 19 & - & - & 5 & 10 & 2 & 1 & 2 & 8 & 1 & 63 \\
\hline Mowers & 12 & 21 & 30 & 4 & 3 & 14 & - & 4 & 5 & 6 & - & 8 & 106 \\
\hline Sprayers & 15 & 20 & 20 & 5 & 6 & 5 & 3 & 3 & 3 & 5 & 2 & 7 & 94 \\
\hline Decorticators & - & 3 & - & - & - & - & - & - & - & - & - & - & 3 \\
\hline Winnowers & 14 & 14 & 24 & 6 & 3 & 6 & - & 2 & 1 & 4 & 5 & 2 & 81 \\
\hline Trucks & 10 & 22 & 27 & 10 & 4 & 3 & 6 & 13 & - & 2 & - & 6 & 103 \\
\hline $\begin{array}{l}\text { Cotton } \\
\text { Pickers }\end{array}$ & 2 & - & - & - & 1 & - & - & - & - & - & - & - & 3 \\
\hline Total (\%) & 12.2 & 18.5 & 30.4 & 3.8 & 4.9 & 8.7 & 4.9 & 3.1 & 3.2 & 5.3 & 3.6 & 2.5 & 100 \\
\hline
\end{tabular}


Table 7: Operators knowledge of machinery operation

\begin{tabular}{lll}
\hline Machinery & Frequency & Percentage (\%) \\
\hline Tractors & 89 & 74.8 \\
Ploughs & 89 & 74.8 \\
Cultivators & 83 & 69.7 \\
Ridgers & 89 & 74.8 \\
Harrows & 89 & 74.8 \\
Plants & 82 & 68.9 \\
Seeddrills & 87 & 73.1 \\
Shellers & 84 & 70.6 \\
Fertilizer applicator & 91 & 76.5 \\
Sprayers & 119 & 100 \\
Mowers & 79 & 66.4 \\
Rice Combine harvester & 81 & 68.1 \\
Threshers & 86 & 72.3 \\
Decorticators & 55 & 46.2 \\
Winnowers & 86 & 72.3 \\
Trucks & 92 & 77.3 \\
Cotton pickers & 57 & 47.9 \\
\hline
\end{tabular}

Table 8: Operators knowledge of machinery maintenance

\begin{tabular}{llllllll}
\hline Machinery & $\begin{array}{l}\text { Obsolete } \\
\text { ness (\%) }\end{array}$ & $\begin{array}{l}\text { Carless } \\
\text { operators } \\
(\%)\end{array}$ & $\begin{array}{l}\text { Lack-of } \\
\text { Spare-parts } \\
(\%)\end{array}$ & $\begin{array}{l}\text { Over } \\
\text { loading (\%) }\end{array}$ & $\begin{array}{l}\text { Poor } \\
\text { maintenan } \\
\text { ce (\%) }\end{array}$ & $\begin{array}{l}\text { Poor } \\
\text { Storage } \\
(\%)\end{array}$ & $\begin{array}{l}\text { Poor } \\
\text { Management } \\
(\%)\end{array}$ \\
\hline Tractors & 71.3 & 70.4 & 75.3 & 65.0 & 38.3 & 72.3 & 82.3 \\
Ploughs & 60.4 & 65.5 & 75.2 & 72.3 & 27.4 & 72.3 & 75.2 \\
Harrows & 66.3 & 75.3 & 82.4 & 75.0 & 28.6 & 73.6 & 78.8 \\
Ridgers & 55.0 & 65.2 & 85.4 & 76.0 & 39.5 & 76.4 & 81.6 \\
Cultivators & 50.9 & 63.5 & 65.6 & 79.0 & 23.0 & 77.3 & 82.2 \\
Planters & 60.2 & 54.8 & 65.3 & 82.3 & 33.0 & 65.9 & 85.3 \\
Seeddrills & 58.3 & 68.1 & 75.3 & 61.4 & 24.6 & 63.9 & 77.3 \\
Shellers & 70.3 & 45.0 & 75.4 & 68.8 & 23.0 & 72.8 & 72.8 \\
Fertilizer applicator & 60.4 & 70.6 & 85.4 & 65.4 & 24.1 & 81.2 & 73.6 \\
Sprayers & 60.8 & 45.5 & 75.0 & 65.8 & 28.2 & 65.4 & 64.3 \\
Mowers & 62.4 & 60.2 & 66.1 & 67.6 & 35.8 & 72.3 & 66.2 \\
Combine harvesters & 63.0 & 62.5 & 72.8 & 72.4 & 32.4 & 72.3 & 92.1 \\
Threshers & 63.2 & 73.3 & 72.2 & 70.8 & 29.8 & 78.1 & 75.2 \\
Decorticators & 63.0 & 52.1 & 64.3 & 75.5 & 26.3 & 76.2 & 73.7 \\
Winnowers & 52.4 & 62.6 & 58.4 & 68.1 & 32.4 & 74.6 & 74.8 \\
Truckers & 66.8 & 44.9 & 66.0 & 69.1 & 31.9 & 50.8 & 75.2 \\
Cotton pickers & 63.3 & 55.8 & 72.9 & 72.9 & 40.1 & 53.4 & 77.0 \\
Mean (\%) & 61.9 & 60.1 & 72.0 & 71.9 & 31.6 & 56.0 \\
\hline
\end{tabular}

Table 9: Causes of Machine failures

\begin{tabular}{llll}
\hline Machinery & Adequate knowledge (\%) & Little knowledge (\%) & No Knowledge (\%) \\
\hline Tractors & 79.8 & 18.0 & 2.2 \\
Ploughs & 75.0 & 20.0 & 5.0 \\
Cultivators & 78.0 & 28.0 & 2.0 \\
Ridgers & 75.0 & 18.0 & 7.0 \\
Harrows & 75.0 & 17.0 & 6.0 \\
Planters & 70.0 & 24.0 & 4.0 \\
Seeddrills & 75.0 & 21.0 & 4.6 \\
Shellers & 50.4 & 45.0 & 10.0 \\
Fertilizer applicator & 73.0 & 17.0 & 10.0 \\
Sprayers & 73.0 & 17.0 & 5.0 \\
Combine Harvest & 75.0 & 20.0 & 4.0 \\
Threshers & 78.0 & 18.0 & 5.0 \\
Decorticators & 75.0 & 20.0 & 5.0 \\
Winnowers & 76.0 & 20.0 & 5.0 \\
Trucks & 75.0 & 20.0 & 5.0 \\
Cotton pickers & 75.0 & 20.0 & \\
\hline
\end{tabular}




\section{CONCLUSION AND RECOMMENDATIONS}

Results obtained from the survey showed that 66.8 to $100 \%$ of the operators in the various agricultural organisations are experienced and competent in operating the farm machineries, 50.4 to 79.8 have good knowledge of machine maintenance. This means good experience of operation and maintenance practices. $64.9 \%$ of the available machines are in good working conditions, $21.6 \%$ are not functional but are serviceable while $14.5 \%$ are out-rightly down and were not serviceable. Most of the failures encountered during operations were as a result of poor management, inadequate maintenance, lack of spare parts, overloading, careless operations and poor storage of the machines after use. The following recommendations should therefore be adhered to, for improved and/or sustainable mechanization of agricultural operation in the area.

* The whole engineering systems management should be reorganized in addition to the little effort of the operators to effect proper care and maintenance of machinery and equipment available in the state to increase efficiency and operation of these machineries.

* Maintenance facilities should be properly equipped; the efficiency of operation of any farm machine depends highly on the attention given to it to upkeep the service life standard of such equipment and/or machine.

* Opportunities should be given to operators for workshops, seminar programmes and courses to update their knowledge of machine operations and maintenance.

* Operators should be made to avoid such attitudes like overloading the machine, irregular inspection of machine before and after use, and carelessness that will result to operational failures or breakdown during operation.

\section{REFERENCES}

[1] Odigboh, E.U. "Continuing Controversies on Tillage Mechanization in Nigeria", Journal of Agricultural Science and Technology, Vol. 1, Number 1, 1991. pp. 2-3.
[2] McColley, H.F. and Martin J.W. Introduction to Agricultural Engineering, McGraw-Hill Book Company Inc, New York, 1995.

[3] Adeguloye, F.O. "Skilful Engineering Management for Maintenance of Farm Tractors", Proceedings of the International Conference of the Nigerian Institution of Agricultural Engineers; 1996, vol. 18: pp. 368-371.

[4] Ahamad D and Kumar. "Maintenance Decision for Farm Tractors in Allahabad District", Indian Journal of Agricultural mechanization in Asia, Africa and Latin America, Vol. 27, Number 2, 1996. pp. 15-17.

[5] Maradum, U. M., Sanusi, U. M. and Akubuo, C. 0 (2013). "Survey Study of Farm Tractor Management: A Case Study of Zamfara State", Nigerian Journal of Technology, Vol. 32, Number 1, 2013. Pp. 23-125.

[6] Onwualu, A. P., Oluka, S. I. and Offiong, A. Principles of Engineering project Management, SNAAP Press Ltd. Enugu, 2002.

[7] Ofodile, I. E. "Maintenance Management of Low Cost Plants and Equipments", Proceedings of the International Conference/Workshop on Engineering for Accelerated Rural Development, 1991.

[8] Monk, J. G. Operations Management: Theory and problems, (1 ${ }^{\text {st }}$ Edition), McGraw-Hill New York, 1982.

[9] Norman, R. G. Production Planning and Control: Mechanical Engineers Reference Book (11 ${ }^{\text {th }}$ Edition), Butter Worth, Boston, 1992.

[10] Oduma, O., Eze, P. C. and Onuoha, S. N. "A Survey of Farm Machinery and Maintenance in Ebonyi State", Journal of Experimental Research: An Official Publication of Enugu State University of Science and Technology, Vol.1, Number 2, 2013. Pp. 12-18.

[11] Bello, S. R., Adegbulugbe, T. A. and Simon, O. O. Farm Power and Machinery: Maintenance, Repairs and Operations, Climax Printers, Enugu, 2010.

[12] Oluka, S. I, Onwualu, A. P. and Eneh, I. I. Engineer-inSociety, SNAAP Press Ltd. Enugu, 1999.

[13] Ogunlade, I, Alabi, K. M. and Olaoye, J. O. (2004): "Socio-Economic Characteristics and Maintenance Knowledge of Tractor Operators in Kwara State, Nigeria", Proceedings of Nigeria Institution of Agricultural Engineers/Annual Conference, 2004. pp. 108-115. 